\title{
Investigation of Sound Transmission Loss Through Sandwich Panel with Foam Core
}

\section{Hatem Hadi Obeid}

Department of Mechanical Engineering, College of Engineering,University of Babylon,

\section{drhatemhadi@yahoo.com}

\section{Abstract}

In the past years, customer and consumer request are increased for performance sound. Where vibration and noise characteristics are made of important design criteria. The vibro- acoustic behavior is considered in the composite sandwich, important research topic to provide a suitable design with consumer requirements.

The sound intensity method is widely using to measure the sound transmission loss between two rooms. This method are used with a composite materials, that are consist of two steel layers between them one layer for core. This paper provides a brief description of the sound intensity method and it is depended on ISO140[1]. Finite Element Method (FEM) are used to comparison with experimental results.The core of different thickness was used to study its effect on acoustic insulation. The experimental and theoretical results are shown, that the value of sound transmission loss are increased by rates of $6 \mathrm{~dB}$ when the core thickness is doubled .

Keywords: Sound intensity method, Sound Transmission Loss (STL), Sandwich Panel, Vibroacoustic analysis.

\section{LIST OF SYMBOLS}

\begin{tabular}{|cccc|}
\hline Symbol & Definition & Dimensions & Units \\
\hline $\boldsymbol{c}$ & Speed of sound & $\mathrm{LT}^{-1}$ & $\mathrm{~m} / \mathrm{s}$ \\
\hline $\mathbf{p}_{\mathbf{0}}$ & Reference sound pressure. & $\mathrm{FL}^{-2}$ & $\mathrm{pa}$ \\
\hline $\mathbf{p}$ & sound pressure & $F L^{-2}$ & $\mathrm{pa}$ \\
\hline $\mathbf{S}_{\mathbf{w}}$ & Area of the common wall & $\mathrm{L}^{2}$ & $\mathrm{~m}^{2}$ \\
\hline $\mathbf{S}_{\mathbf{2}}$ & $\begin{array}{c}\text { total surface area of receiving } \\
\text { room }\end{array}$ & $\mathrm{L}^{2}$ & $\mathrm{~m}^{2}$ \\
\hline $\mathbf{L}_{\mathbf{P 1}}$ and $\mathbf{L}_{\mathbf{P 2}}$ & average sound pressure levels & - & $\mathrm{dB}$ \\
\hline $\mathbf{L}_{\mathbf{I} 1}$ and $\mathbf{L}_{\mathbf{I} 2}$ & average sound intensity & - & $\mathrm{dB}$ \\
\hline $\boldsymbol{\Pi}_{\text {incident }}$ & Intensity incident on wall & $\mathrm{MT}^{-3}$ & $\mathrm{w} / \mathrm{m}^{3}$ \\
\hline $\boldsymbol{\Pi}_{\text {transmitted }}$ & Intensity incident on wall & $\mathrm{MT}^{-3}$ & $\mathrm{w} / \mathrm{m}^{3}$ \\
\hline $\boldsymbol{\alpha}_{\mathbf{2}}$ & absorption for receiving room & $\mathrm{M}^{-3}$ & $1 / \mathrm{m}$ \\
\hline $\boldsymbol{\rho}$ & Mass per unit area & $\mathrm{ML}^{-3}$ & $\mathrm{~kg} / \mathrm{m}^{3}$ \\
\hline $\mathbf{S T L}$ & sound transmission loss & - & $\mathrm{dB}$ \\
\hline
\end{tabular}

\section{Introduction}

Weight reduction is one of the main design drivers of modern engineering and transport structures for aerospace and automotive applications. In this context, the sandwich design principle is playing a major role, as it allows for much higher weight-specific bending stiffness compared to a monolithic structure. A sandwich structure typically consists of two thin and stiff skins, separated by a lightweight 
cellular core. But lightness this sandwich panel, made it tends to cause unwanted noise.

Kwanju Kim et.al.,[2], proposed a prediction method of the STL of the aluminum extruded panel when it was used the finite element analysis and the commercial vibroacoustic program MSC ACTRAN, the results from FEM analysis are compared with those from sound intensity experiments based on ASTM E224902. for obtain the most accurate analysis results, it was applied the boundary conditions of finite element model closer to the real situation. The specimen in the experiment was placed in the test section by 12 clamps and the boundary was sealed with clay to prevent leakage of sound. 4 boundary condition were used, clampedclamped, clamped-free, free-clamped, and finally free-free. This a study was founded, the insulation characteristics could be precisely predicted if accurate cross-sectional shape and the material properties were provided. Because fabricating extruding panels costs much, proposed vibration and sound analyzing method will be useful when predicting the insulation performance.

Edwin et.al.,[3], applied the hybrid method to study sound transmission through a wall in between two rooms. It was depended of a hybridization of displacement- based and energy-based modeling, multiple types walls were used in this test, such as, (gypsum blocks, thicker construction wall and double glass). This hybrid method have been a good, due when the laboratory results have been compared with the computational results, it was a good results.

Raef Cherifa and Noureddine Atalla [4], presented a detailed experimental validation of a general laminate model to predict the vibroacoustic behavior of flat sandwich-composite panels. The accuracy of the model was investigated from a thin and a thick sandwich panel, it were used in this validation, a thin panel representative of a trim panel and a thick panel representative of a skin or floor panel. Both are of a honeycomb (HC) core construction. Several indicators were compared including the structural wavenumber, modal density, damping loss factor, radiation efficiency, and sound transmission loss. That the model was predicted very well the wavenumber (dispersion curves), the modal density, and the radiation.

MP Arunkumar et.al.,[5], studied the sound transmission loss in the cores, that it was using in aerospace engineering applications such as honeycomb, triangular, trapezoidal, cellular, zed, aluminum foam and rohacell foam with aluminum, titanium and epoxy carbon laminate face sheet. 2D FE model was used for analyzing the free and forced vibration response of the sandwich panel and the calculated vibration response was given as an input to Rayleigh integral in order to obtain the sound transmission loss characteristics. It had been studied the effect of (face and core) thickness the honeycomb core sandwich panel on sound transmission loss and it have been able to use the cell size as the parameter to reduce the weight without affecting the sound transmission loss. It was noticed in foam core panel, that the effect of material on sound transmission loss is significant and this can be controlled by varying the density of foam for various material sheet to keep the sound transmission loss in desirable level.

There are many method are applied to study acoustic behavior in sandwich panel. The sound intensity method is widely using to measure the sound transmission loss between two rooms and this method was depended on ISO140[1]. In this work 
Journal of University of Babylon for Engineering Sciences, Vol. (26), No. (6): 2018.

are studied the influence of the thickness layer of foam and air gap layer between two sandwich on sound transmission loss STL.

\section{Theory}

\subsection{Sound Intensity Method.}

In this method two rooms are used, the first room (source room) are reflective chamber. While the second room (receiving room) are semi-anechoic[6].

The STL of each sample was calculated using:

$S T L=L_{p 1 \text { (source room) }}-L_{I 2 \text { (receiving room }}-6$

Where $L_{p 1 \text { (source room ) }}$ is the average sound pressure level measured in the source room, and $L_{I 2 \text { (receiving room }}$ is the average intensity measured in the receiving room. For each sample, average STL values are calculated by averaging the results from the three separate tests [7] .Shown Figure (1)

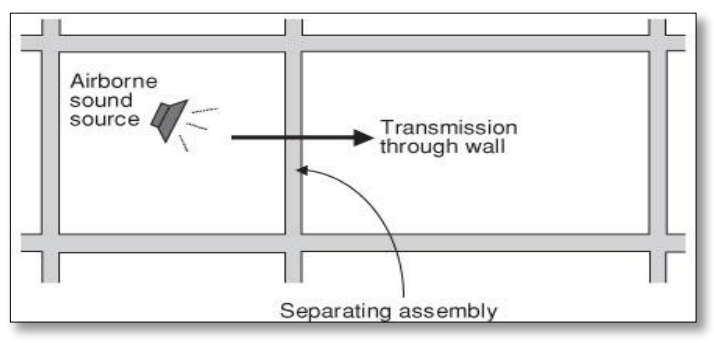

Figure (1): Paths for Sound Transmission [8].

\subsection{Finite Element Analysis}

The Finite Element Method (FEM) is used in this study to conduct sound analysis for sandwich panel, and study the properties of sound waves resulting from the vibration of sandwich panels. In the sound analysis, modeling is done for (Sound pressure in liquid for different frequencies, particle velocity, sound pressure level, attenuation, radiation and dispersion of sound waves etc...). In the analysis, acoustics are taken into account coupling structure reaction with liquid [9].

\subsubsection{Geometrical and Material Properties of Acoustic Room}

In this paper, two acoustic rooms are designed. A window is putted between the two rooms. The first room is the larger (source room) and the second room is the smaller (receive room), as shown in Figure (2).

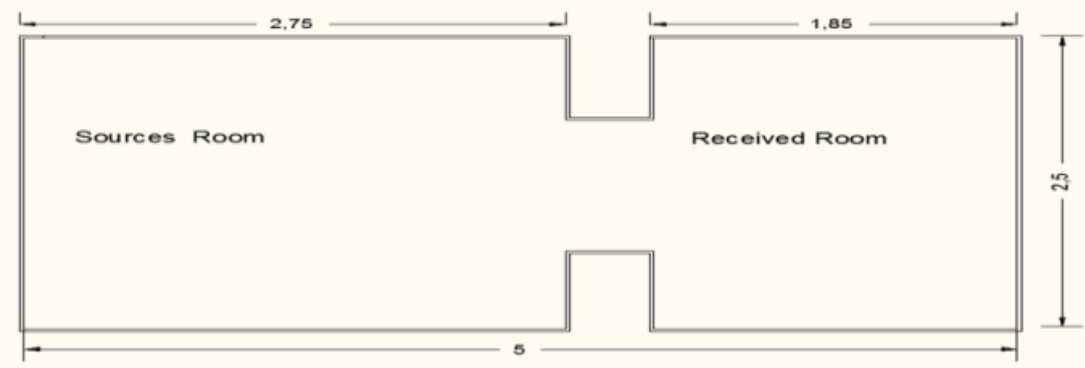

Figure (2): Rooms Acoustic. All Dimension in $\mathbf{m}$. 
Journal of University of Babylon for Engineering Sciences, Vol. (26), No. (6): 2018. follows:

The engineering characteristics and physical parameters of the models are as

1- Skins material: each layer for the skin has thickness $(0.5) \mathrm{mm}$, density 2800 $\mathrm{kg} / \mathrm{m} 3$, Young Modulus of elasticity $198 \mathrm{GPa}$, poison ratio 0.29 . The parameters were taken from standard ASTM A525 Galvanized Steel.

2- Core material: the polyurethane (PU) foam had thickness $(50-100) \mathrm{mm}$, density $40 \pm 2 \mathrm{~kg} / \mathrm{m}^{3}$, Young Modulus of Elasticity $\left(E_{1}=0.21, E_{2}=0.205, E_{3}=0.32\right) \mathrm{Mpa}$, Poisson ratio $v_{1}=0.18, v_{2}=0.2, v_{3}=0.33$. ASTM D1621-04.

3- Air media in the source room: the air characteristics of the first room (source room) consist of density $1.12 \mathrm{~kg} / \mathrm{m} 3$, sound speed $343 \mathrm{~m} / \mathrm{s}$.

4- Air media in the receive room: the air characteristics of the second room (receive room) consist of density $1.12 \mathrm{~kg} / \mathrm{m} 3$, sound speed $343 \mathrm{~m} / \mathrm{s}$.

The Beta absorption should be between $0-1$, where a coefficient of 0 indicates none of the sound is absorbed, and a coefficient of 1 indicates that $100 \%$ of it is absorbed. The sound absorption coefficient in two rooms are differed with the band frequency, ISO140 [1].

\subsubsection{Boundary Condition}

Boundary condition of all models clamped from all sides (Constrain all displacements to zero at the walls). Shown in Figure (3).

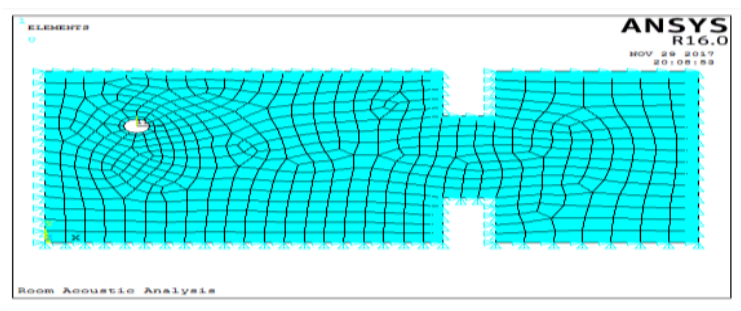

Case (1)

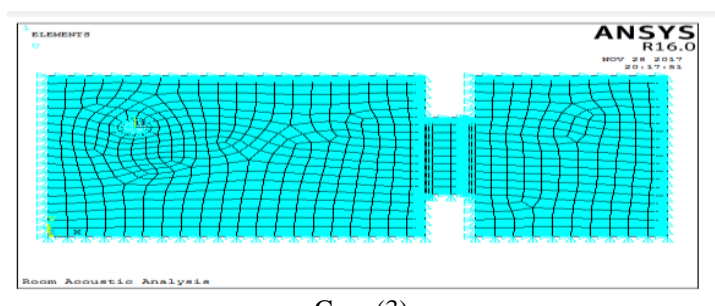

Case (3)
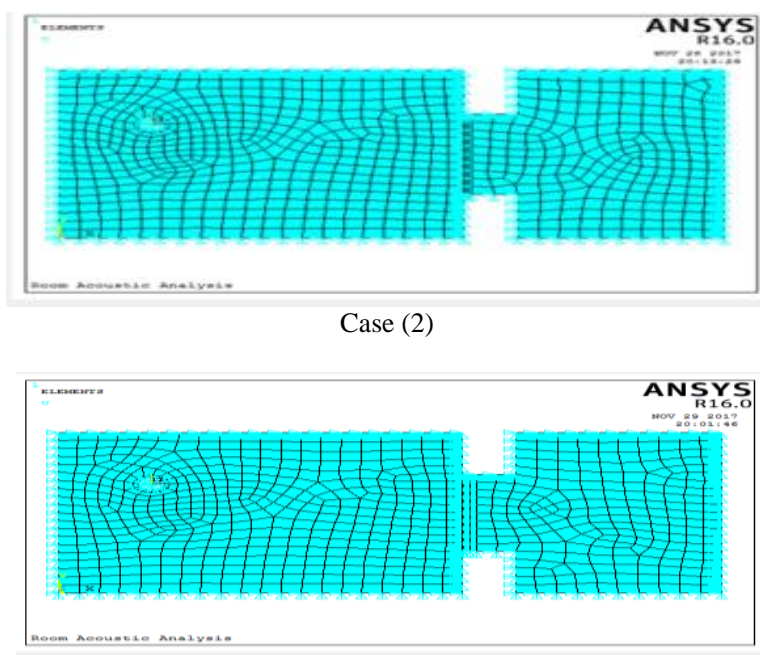

Case (4)

Figure (3): Boundary Condition of all Models of Current Work.

\subsubsection{Element Type}

Are applied four ANSYS element types are used for in the acoustic analyses:

1-Element (FLUID29). 2-Element (FLUID30).

3-Element (FLUID129). 4-Element (FLUID130). [10], shown Figure (4). 


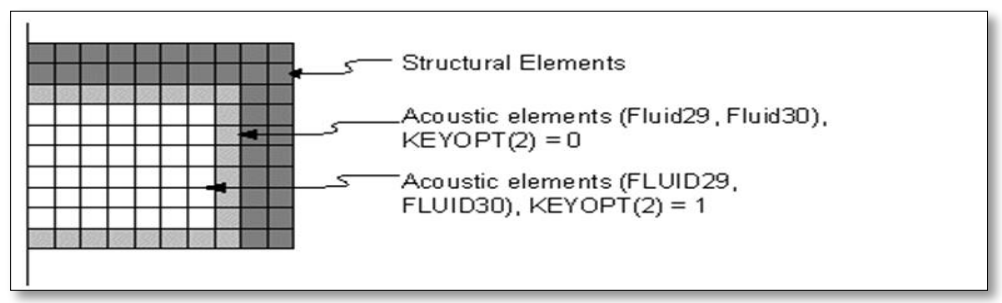

Figure (4): 2-D Acoustic Model [11].

\subsubsection{Mesh Convergence}

Four cases study are applied, as following:

1- Open the Partition between two rooms.

2- Closed the Partition between two rooms by one sandwich (5) $\mathrm{cm}$ thickness core.

3- Closed the Partition between two rooms by two sandwiches (5) $\mathrm{cm}$ thickness core. 4- Closed the Partition between two rooms by one sandwich (10) $\mathrm{cm}$ thickness core.

FEM models for room acoustic are shown in Figure (5) .
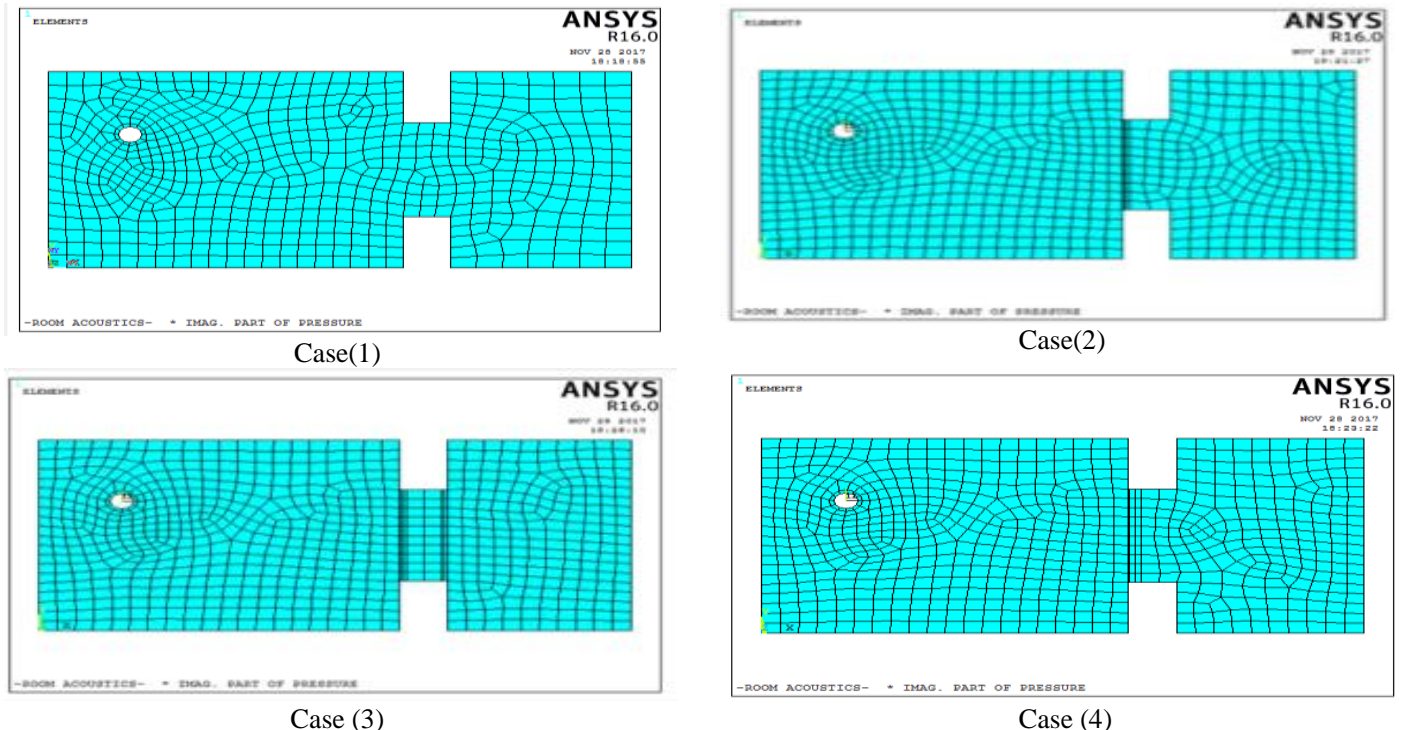

Figure (5): Finite Element Models of rooms acoustic.

\section{Experimental work}

\subsection{Test Facilities (Sound Intensity Method)}

The sound transmission loss (STL) was measured by used sound intensity method. Two rooms are used in this method, the first and larger room was called a source room and the second and the smaller room was called received room. The test procedure is based on international organization for Standardization ISO140[1]. As Shown in Figure (6). 


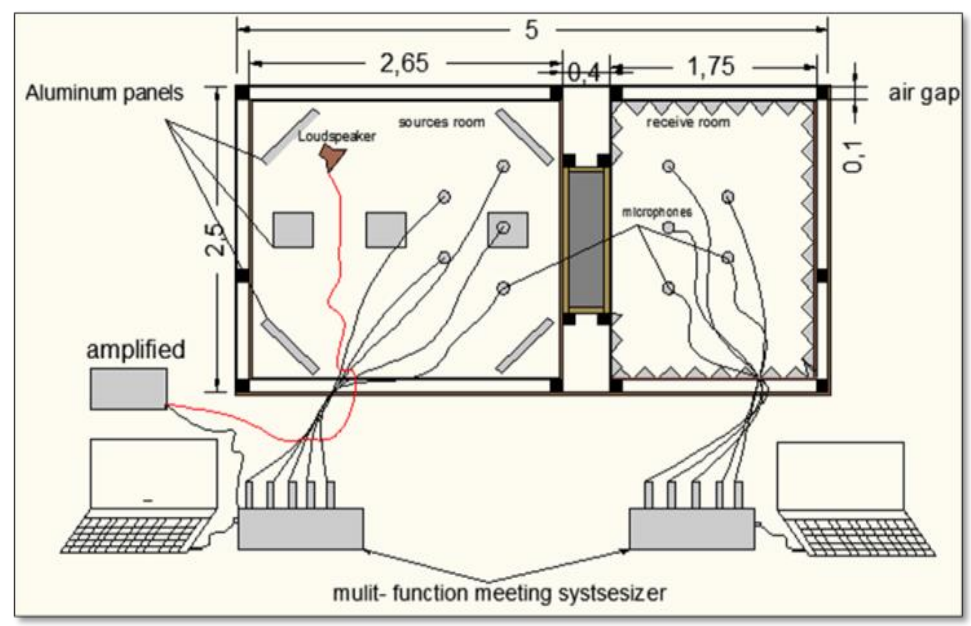

Figure (6): Design of Test Room for Transmission Loss (all Dimensions m).

The two horizontally adjacent rooms are used. the two rooms have the minimum flanking sound transmission. the sound transmission path between the two rooms is directly through the specimen ISO140[1]. Two rooms are made from wood plates installed on iron structures (box iron section 2") and (box iron section 4") pillars at each building corner, between each the two woods plates $(4 \mathrm{~mm})$ thickness, the air layer $(100 \mathrm{~mm})$ thick to increase the sound insulation of the rooms outer perimeter.

In sources room are distributed reflective aluminum panels in all corners, and in addition, the convex reflective panels are suspended on the ceiling. Loudspeaker is installed in one of the corner of the source room to amplify the sound source; the floor of the source room is covered with layers of aluminum panels. As shown in Figure (7).

In the received room all the walls and the floor, it is covered by eggs plates, the floor of the received room was covered by rubber plates to increase sound absorption in addition to egg layers. The egg layers help absorb the acoustic waves that reach the room it makes semi-echo room. Five microphone are placed in each room and the distance between each microphone and each wall is $(0.5 \mathrm{~m})$. The height of the microphone on the ground is more than $(0.7 \mathrm{~m})$, shown in Figure (8). ISO140[1] . In the middle of the wall connecting the two rooms is window where the samples are tested. All the samples are dimensions $(950 * 1300) \mathrm{mm}$. ISO140[1] .

The samples are supported along the edge by using the bolt $(10 \mathrm{~mm}$ diameter and $150 \mathrm{~mm}$ long), it is used the same torque to tighten the bolts by mechanical bolt fasteners with the addition of putty around the rim to minimize the leakage of sound through the sample.

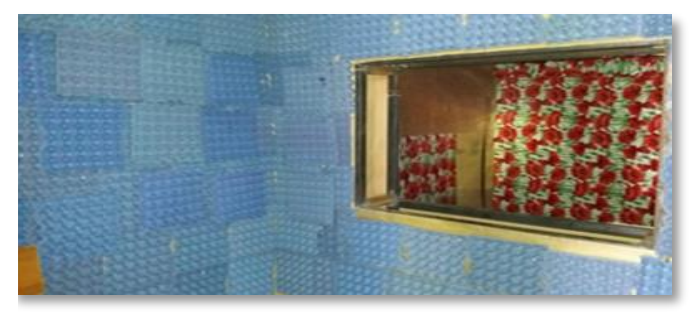

(a)

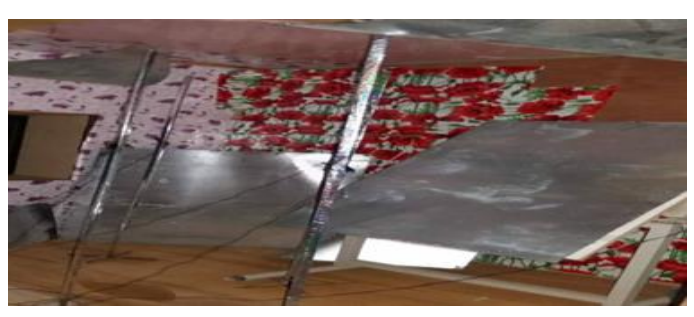

(b)

Figure (7): Design Rooms Test:(a) Receiving Room.(b)Source Room. 


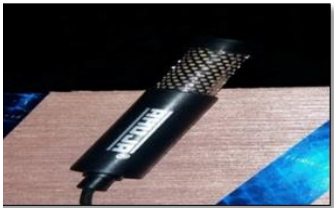

Microphones

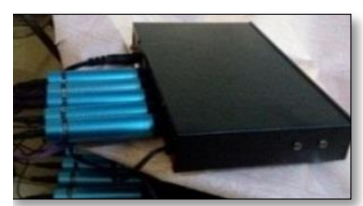

Mulit- function meeting systsesizer.

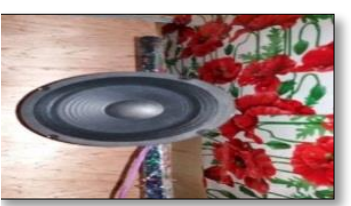

Loudspeaker

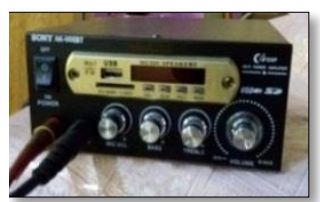

Amplified

Figure (8): The Device Used in The Test.

The (pink noise) sound source was generated through the loudspeaker after amplifying the signal. In order to receive the sound wave transmitted in source room, five microphones were distributed, ISO140[1]. These microphones were connected to the mulit- function meeting systsesizer to collect signals recorded by these clips in one signal. Through the (Spectra plus-SC) program [12]. The signal and the sound pressure measurement of this room are analyzed at different frequencies $(0-5000) \mathrm{Hz}$. In the receiving room also, five microphones are distributed in the same way as and all the microphones are connected to the multi- function meeting systsesizer and from there to the signal analysis. For more information visit the official website (www.spectraplus.com), as shown in Figure (9).

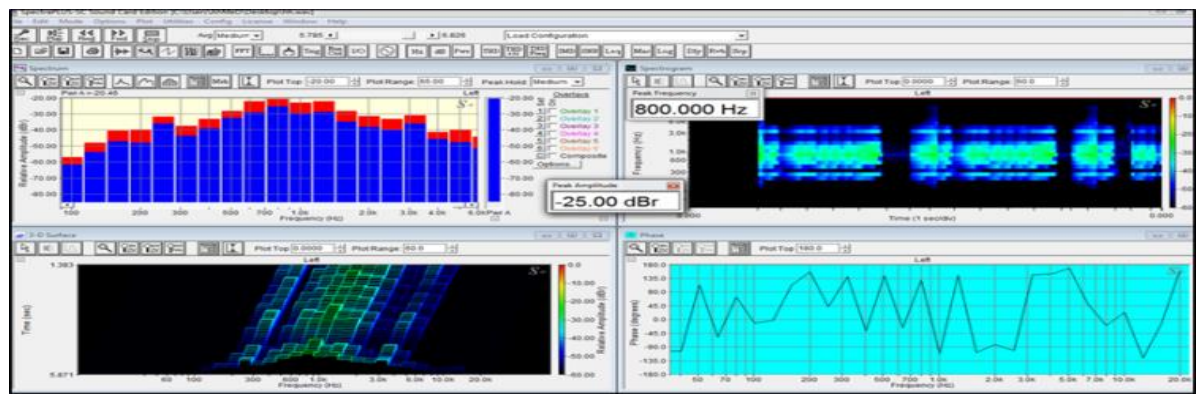

Figure (9): (Spectra plus-SC) Program.

\section{Results and Discussions}

\section{1 (STL) Results Open the Partition Between Two Rooms}

Figure (10) represents (SPL) values for experimental testing for one-third octave band.

Table (1) represented the comparison results between theoretical and experimental and error percentage.

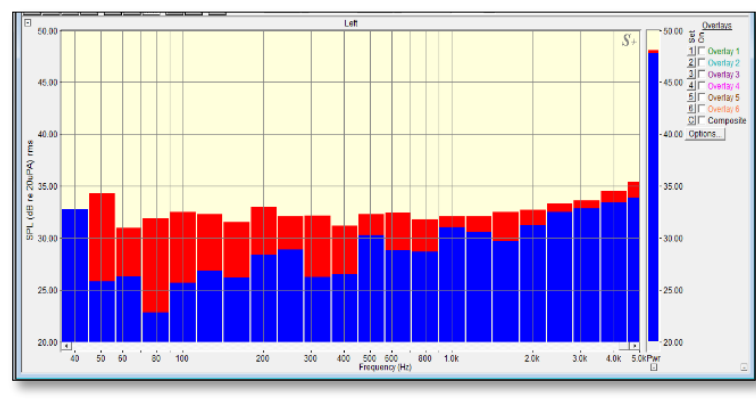

(a)

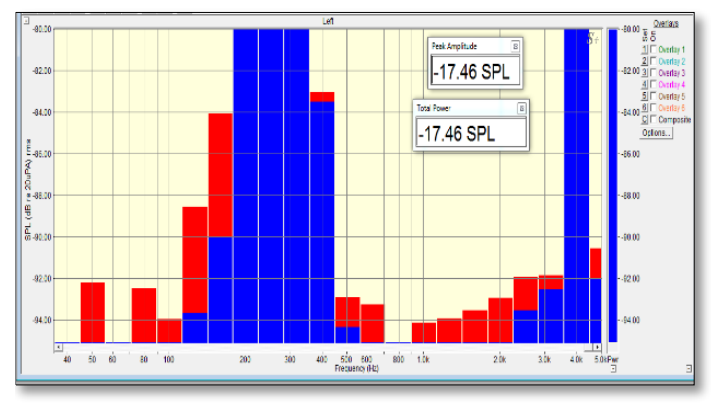

(b)

Figure (10): Experimental (SPL) for Two Rooms When Open the Partition, (a) Resaved Room.(b) Sources Room. 
Journal of University of Babylon for Engineering Sciences, Vol. (26), No. (6): 2018.

Table (1): Comparison (STL) Results between Theoretical and Experimental and Error Percentage.

\begin{tabular}{|cccccccc|}
$\begin{array}{c}\text { One Third } \\
\begin{array}{c}\text { Octave Band } \\
\text { Frequency }(\boldsymbol{H z})\end{array}\end{array}$ & $\begin{array}{c}\text { Experim } \\
\text { ental } \\
\text { STL dB B }\end{array}$ & $\begin{array}{c}\text { Theo } \\
\text { retica } \\
l \text { STL } \\
\text { dBB }\end{array}$ & Error\% & $\begin{array}{c}\text { One Third } \\
\text { Octave Band } \\
\text { Frequency }(H z)\end{array}$ & $\begin{array}{c}\text { Experi } \\
\text { mental } \\
\text { STL } \\
\text { dB }\end{array}$ & $\begin{array}{c}\text { Theoreti } \\
\text { cal STL } \\
d B\end{array}$ & Error\% \\
\hline 100 & 1 & 1.13 & 13 & 400 & 10 & 8.43 & 15.7 \\
\hline 125 & 2 & 1.9 & 5 & 500 & 1.9 & 1.76 & 7.36 \\
\hline 160 & 7 & 7.8 & 11.428 & 630 & -1.3 & -1.12 & 13.85 \\
\hline 200 & 9 & 10.25 & 13.89 & 800 & -2.1 & -2.24 & 6.67 \\
\hline 250 & 8 & 9.2 & 15 & 1000 & -3.7 & -3.25 & 12.16 \\
\hline 315 & 16 & 13.75 & 14.06 & & & & \\
\hline
\end{tabular}

Figure (11) exhibits comparison the experimental and theoretical STL results. The STL values are stable and almost low, because the amount of sound energy are emitted from the source room to receiving room, due the open partition between the two rooms, except for the region with frequencies ranging from (100-200) are noted a rise in the values of STL, this is due to the cavity of the sound emitting chamber. The amplitude values difference is due to the choice a unitary sound source in the numerical model. This does not affect the results in terms of STL [2---13].

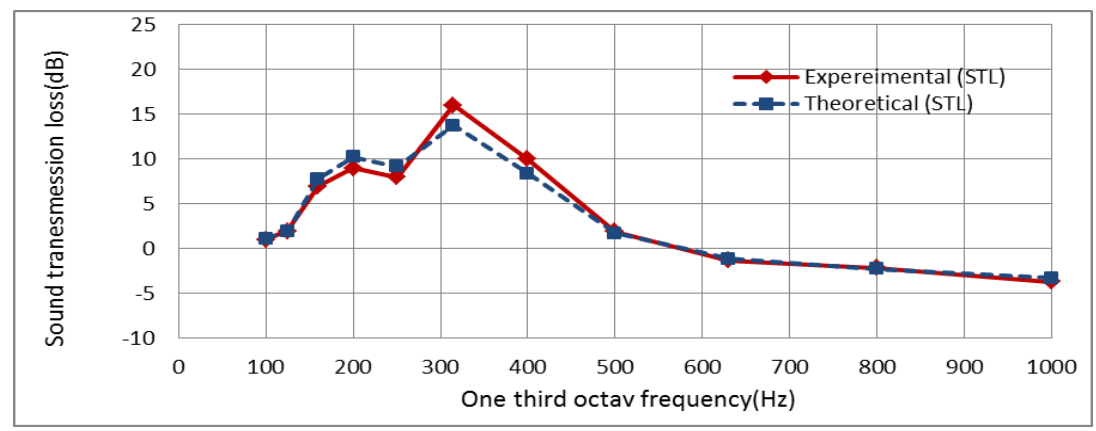

Figure (11): Comparison Theoretical and Experimental STL Results

For Open the Partition Between Two Rooms.

Figure (12) appears the FEM models (mash and sound pressure) inside the rooms at the one third-octave frequency.

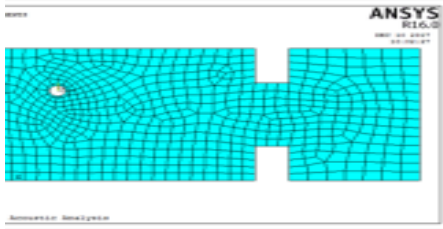

ELEMENT

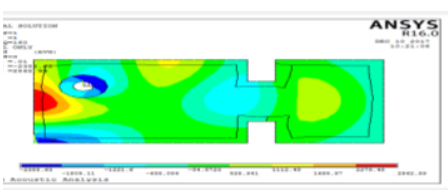

$\mathrm{Fn}=160$

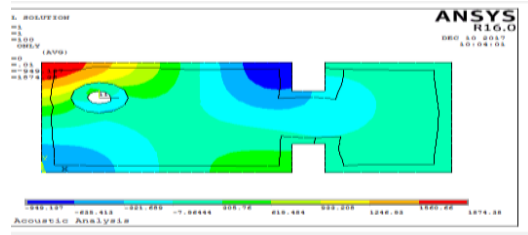

$\mathrm{Fn}=100$

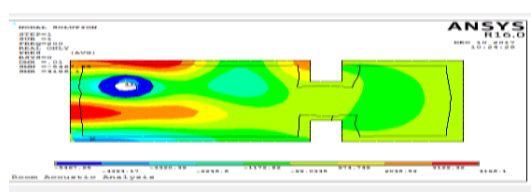

$\mathrm{Fn}=200$

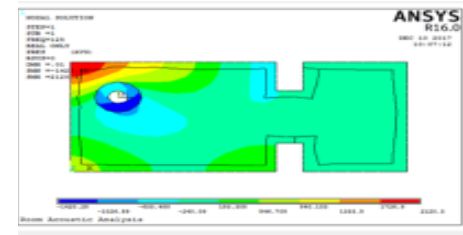

$\mathrm{Fn}=125$

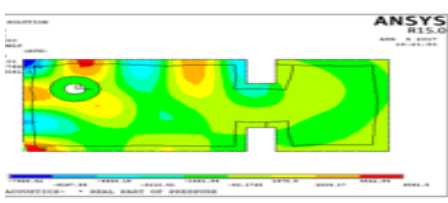

$\mathrm{Fn}=250$ 
Journal of University of Babylon for Engineering Sciences, Vol. (26), No. (6): 2018.

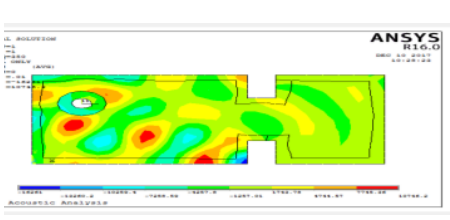

$\mathrm{Fn}=315$

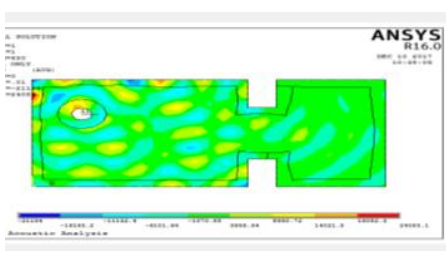

$\mathrm{Fn}=630$

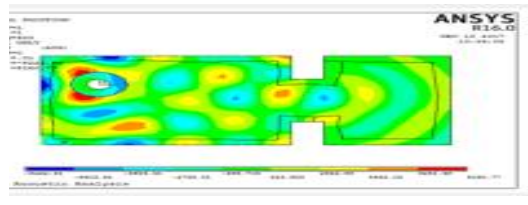

$\mathrm{Fn}=400$

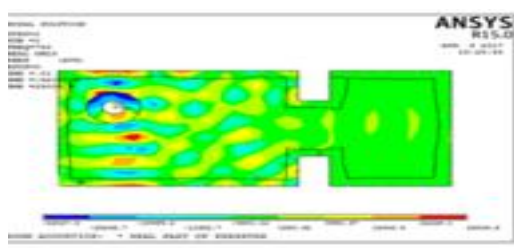

$\mathrm{Fn}=800$

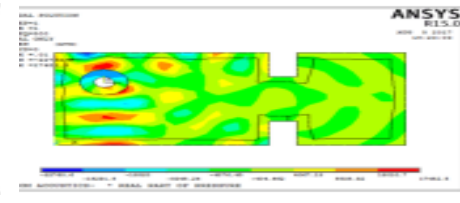

$\mathrm{Fn}=500$

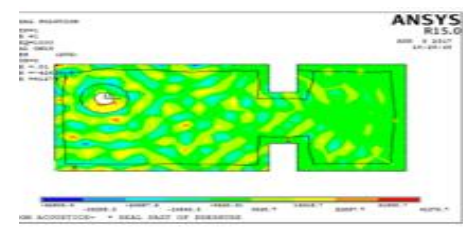

$\mathrm{Fn}=1000$

Figure (12): FEM Models Sound Pressure in Rooms at the One-Third Octave Frequency.

\subsection{STL Results For One Sandwich Panel 50mm Thickness Core}

In this case's study, one sandwich panel are used to close the partial between two rooms. Figure (13) provides (SPL) values for experimental test in one third octave band and for the two rooms .Table (2) represents the comparison results between theoretical and experimental and error percentage.

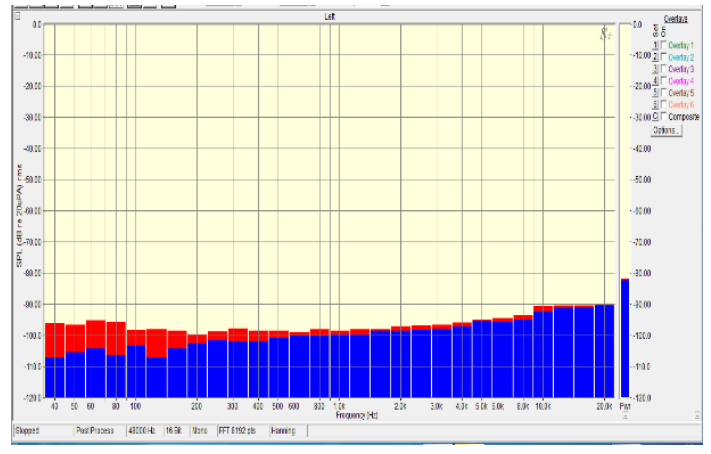

(a)

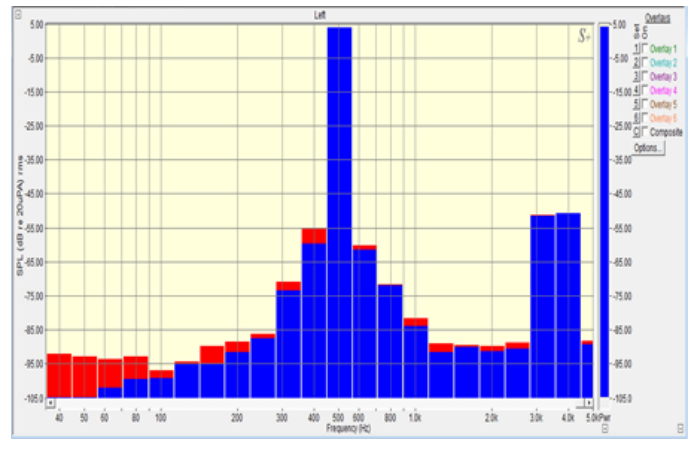

(b)

Figure (13): Experimental (SPL) for Two Rooms When close the Partition Between Rooms by One Sandwich Panel 50mm Thickness for Core,(a) Resaved Room.(b) Sources Room.

Table (2): (Experimental and Theoretical ) STL Results, closed the Partition Between Two Rooms and Error Percentage.

\begin{tabular}{|c|c|c|c|c|c|c|c|}
\hline $\begin{array}{l}\text { One Third } \\
\text { Octave Band } \\
\text { Frequency }(\mathrm{Hz})\end{array}$ & $\begin{array}{l}\text { Experim } \\
\text { ental } \\
\text { STL dB }\end{array}$ & $\begin{array}{l}\text { Theoreti } \\
\text { cal STL } \\
d B\end{array}$ & Error\% & $\begin{array}{c}\text { One Third } \\
\text { Octave } \\
\text { Band } \\
\text { Frequency }(\mathrm{Hz})\end{array}$ & $\begin{array}{l}\text { Experim } \\
\text { ental } \\
\text { STL dB }\end{array}$ & $\begin{array}{l}\text { Theor } \\
\text { etical } \\
S T L \\
d B\end{array}$ & $\begin{array}{c}\text { Error } \\
\%\end{array}$ \\
\hline 100 & 0.6 & 0.5 & 16.67 & 1600 & 39 & 36 & 7.69 \\
\hline 200 & -5.8 & -5.1 & 12.1 & 2000 & 28.7 & 26.5 & 7.67 \\
\hline 250 & 8 & 6.8 & 15 & 2500 & 16.9 & 18.7 & 10.65 \\
\hline 500 & 4.5 & 5.1 & 13.333 & 3150 & 24 & 21.3 & 11.25 \\
\hline 800 & 22.88 & 19.5 & 14.77 & 4000 & 31.5 & 29.4 & 6.667 \\
\hline 1000 & 29 & 32.4 & 11.72 & 5000 & 37 & 33.1 & 10.54 \\
\hline
\end{tabular}


Journal of University of Babylon for Engineering Sciences, Vol. (26), No. (6): 2018.

Figure (14) represents the comparison (STL) among the experimental and theoretical. The stiffness region is shown at very low frequencies, the resonance panel region are appeared from (200 and 500) Hz, when it is observed decrease in STL value, after that begin mass law region is appeared when an increase STL by rate 6dB for each frequency. At frequency $2500 \mathrm{~Hz}$, the coincidence region is shown where a dip in value STL values. At the higher band frequency damping controlled region begin.

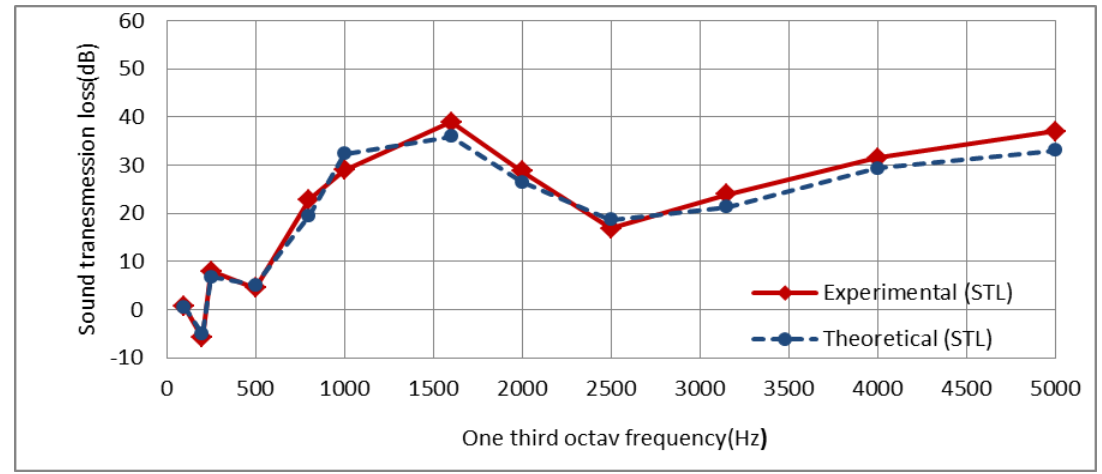

Figure (14): Comparison Theoretical and Experimental STL Results Between Two Rooms for One Third Octave.

Figure (15) appears the FEM models sound pressure inside the Rooms.

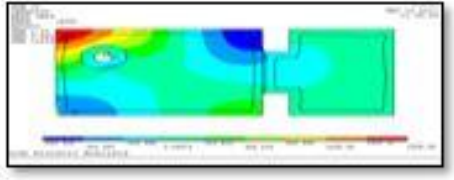

$\mathrm{F}=100 \mathrm{~Hz}$

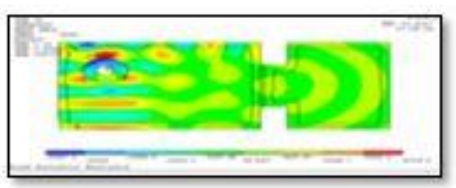

$\mathrm{F}=500 \mathrm{~Hz}$

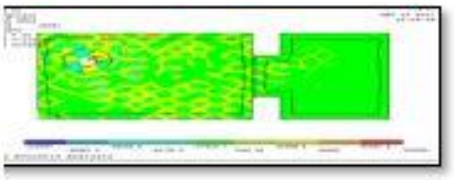

$\mathrm{F}=1600 \mathrm{~Hz}$

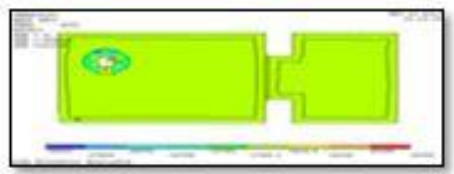

$\mathrm{F}=3150 \mathrm{~Hz}$

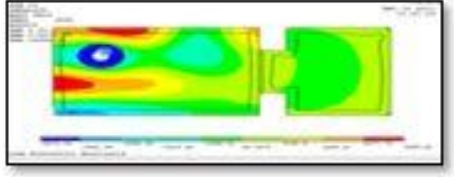

$\mathrm{F}=200 \mathrm{~Hz}$

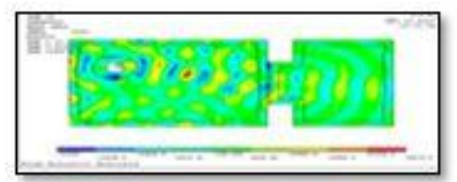

$\mathrm{F}=800 \mathrm{~Hz}$

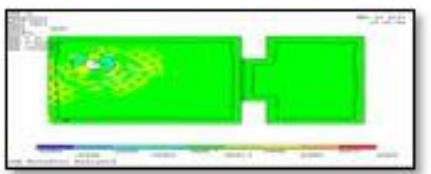

$\mathrm{F}=2000 \mathrm{~Hz}$

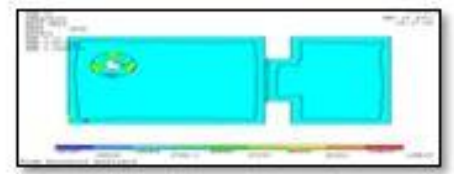

$\mathrm{F}=4000 \mathrm{~Hz}$

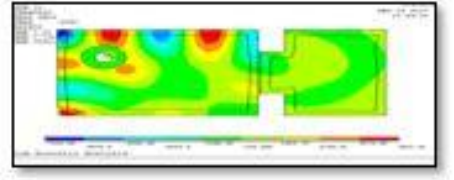

$\mathrm{F}=250 \mathrm{~Hz}$

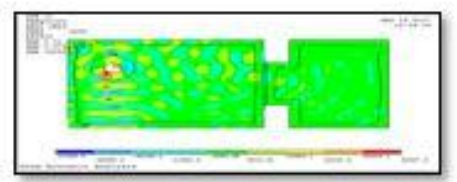

$\mathrm{F}=1000 \mathrm{~Hz}$

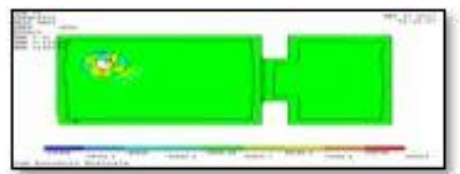

$\mathrm{F}=2500 \mathrm{~Hz}$

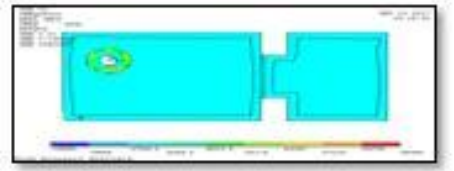

$\mathrm{F}=5000 \mathrm{~Hz}$

Figure (15):FEM Models (Meshes and Sound Pressure) for Case Study One Sandwich Panel (50) mm for Thickness a Core. Between Two Rooms for One Third Octave. 
Journal of University of Babylon for Engineering Sciences, Vol. (26), No. (6): 2018.

\subsection{STL Results For Closed The Partition by Two Sandwich Panel 50 mm For Thickness Core}

Figure (16) provides SPL values of experimental work for one third octave band and two sandwiches panels with $50 \mathrm{~mm}$ core thickness are used to close the partition between the two rooms and the air gap are $280 \mathrm{~mm}$ between the two sandwiches .

Table(3) represented the comparison results between theoretical and experimental and error percentage.

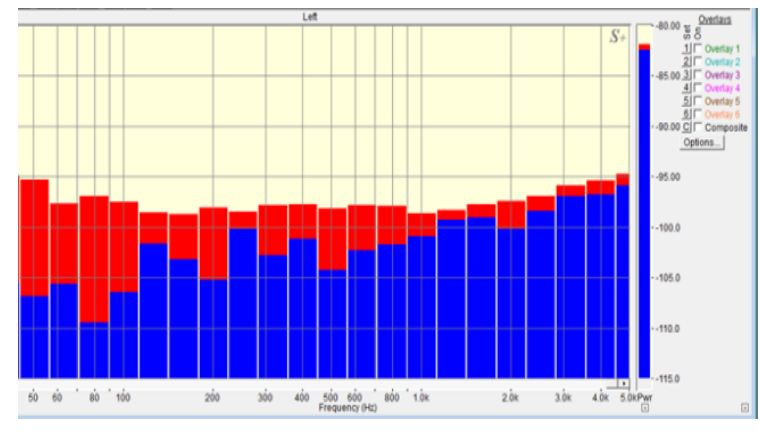

(a)

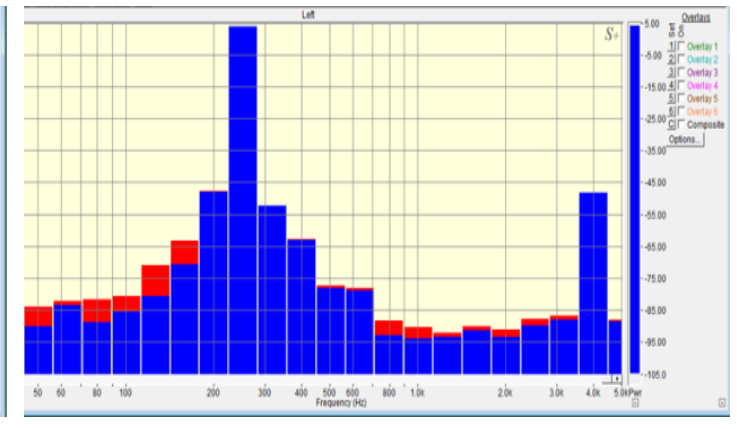

(b)

Figure (16) ): Experimental (SPL) for Two Rooms When Close the Partition Between Rooms by Two Sandwich Panel ,(a) Resaved Room.(b) Sources Room.

Table (3): Comparison (STL) Results Between Theoretical and Experimental and Error Percentage.

\begin{tabular}{|cccccccc|}
$\begin{array}{c}\text { One Third Octave } \\
\text { Band } \\
\text { Frequency }(\mathrm{Hz})\end{array}$ & $\begin{array}{c}\text { Experimental } \\
\text { STL dB }\end{array}$ & $\begin{array}{c}\text { Theoretical } \\
\text { STL dB }\end{array}$ & Error\% & $\begin{array}{c}\text { One Third Octave } \\
\text { Band } \\
\text { Frequency/(Hz) }\end{array}$ & $\begin{array}{c}\text { Experimental } \\
\text { STL dB }\end{array}$ & $\begin{array}{c}\text { Theoretical } \\
\text { STL dis }\end{array}$ & Error\% \\
\hline 100 & 2 & 2.3 & 15 & 1600 & 30 & 28.75 & 4.167 \\
\hline 200 & 6 & 7.1 & 18.333 & 2000 & 18 & 16.12 & 10.444 \\
\hline 250 & 9 & 7.9 & 12.222 & 2500 & 31 & 34.5 & 11.3 \\
\hline 500 & 15 & 13.45 & 10.333 & 3150 & 38 & 42 & 10.53 \\
\hline 800 & 21 & 23.4 & 11.428 & 4000 & 43 & 48.45 & 12.6744 \\
\hline 1000 & 24 & 27.6 & 15 & 5000 & 48 & 46.25 & 3.646 \\
\hline
\end{tabular}

Figure(17) shows the comparison among the experimental and theoretical STL result. In STL curve are shown the stiffness and resonance region isn't found, due it appears in very low frequencies, it is out bands frequencies. The mass law region are increased by rate $6 \mathrm{~dB}$ for each frequency band, but in $2000 \mathrm{~Hz}$, the coincidence region is shown where a dip in value STL values, at the mid and higher frequency band, the damping controlled region are appeared. Through the results are shown higher values of sound transmission losses. due to use two sandwich panel between them air gap. The air gap does to increas absorbing the sound energy, due the friction and viscosity in the air layer.and this results are agreed with literature, Moore[14]. 
Journal of University of Babylon for Engineering Sciences, Vol. (26), No. (6): 2018.

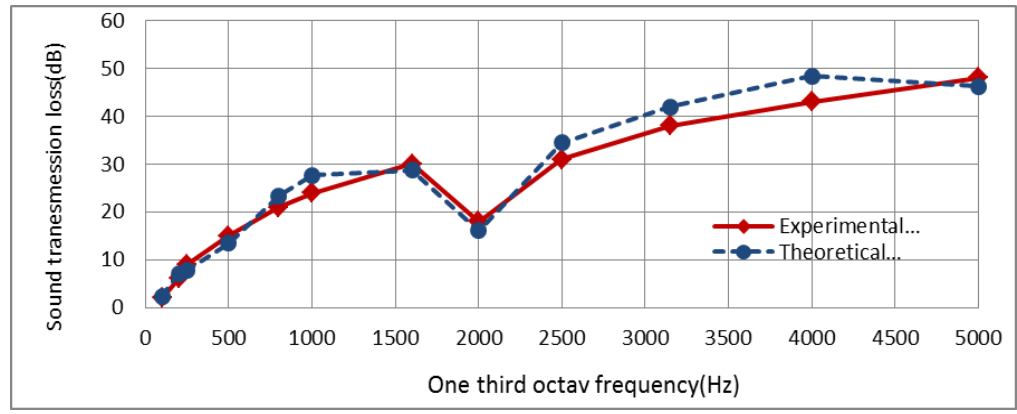

Figure (17) Comparison Theoretical and Experimental (STL), Closed the Partition Between Two Rooms by Using Two Sandwich Panel (50) mm for Thickness for One Third Octave.

Figure (18) appears the FEM models for sound pressure inside the rooms .

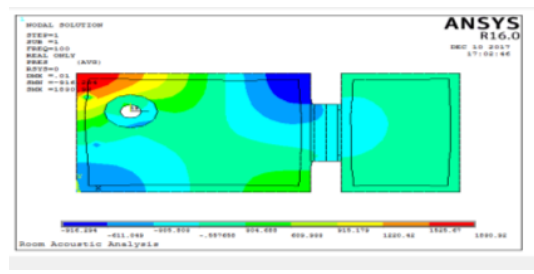

$\mathrm{Fn}=100$

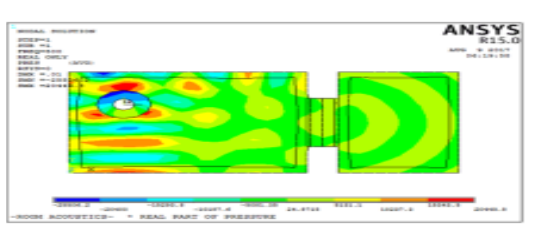

$\mathrm{Fn}=500$

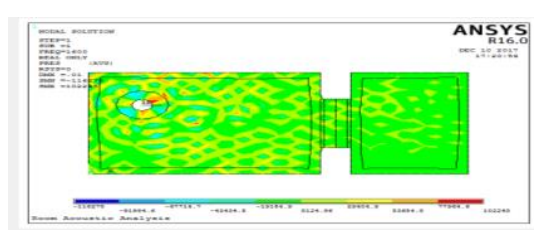

$\mathrm{Fn}=1600$

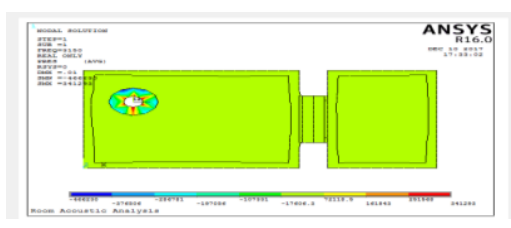

$\mathrm{Fn}=3150$

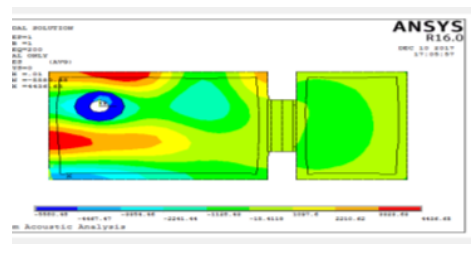

$\mathrm{Fn}=200$

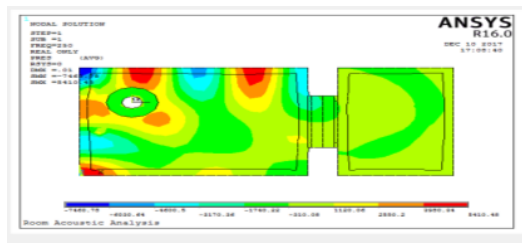

$\mathrm{Fn}=250$

Figure (18) : Continuous Figure

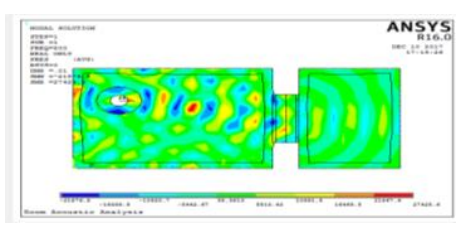

$\mathrm{Fn}=800$

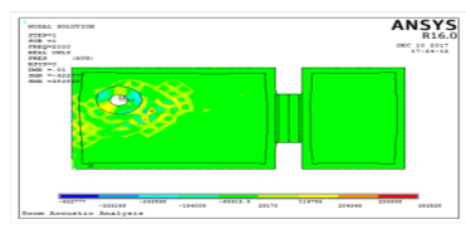

$\mathrm{Fn}=2000$

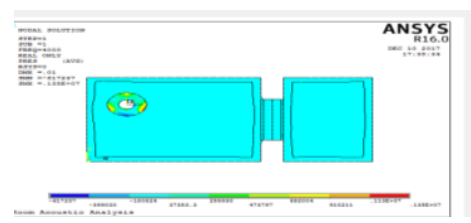

$\mathrm{Fn}=4000$

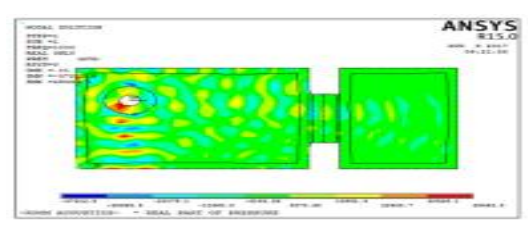

$\mathrm{Fn}=1000$

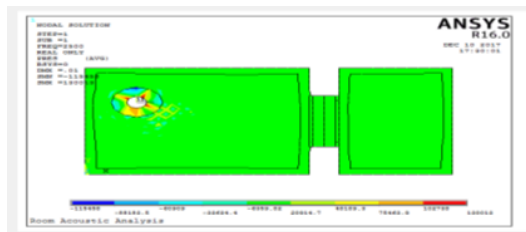

$\mathrm{Fn}=2500$

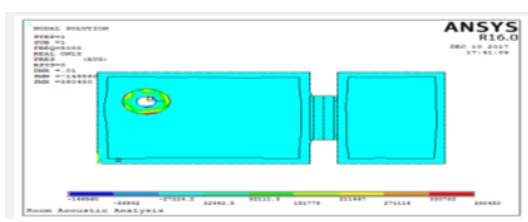

$\mathrm{Fn}=5000$

Figure( 18): FEM Models Sound Pressurefor Case Study closed the Partition between two rooms by Using Two Sandwich Panel (50) $\mathrm{mm}$ for Thickness a Core and air gap Between Them for One Third Octave. 
Journal of University of Babylon for Engineering Sciences, Vol. (26), No. (6): 2018.

\subsection{STL Results For Closed the Partition by One Sandwich Panel $100 \mathrm{~mm}$ for Thickness Core}

Figure (19) appears the SPL values for experimental work for one third-octave band and one sandwich panel with $100 \mathrm{~mm}$ core thickness are used to close the partition between the two rooms.

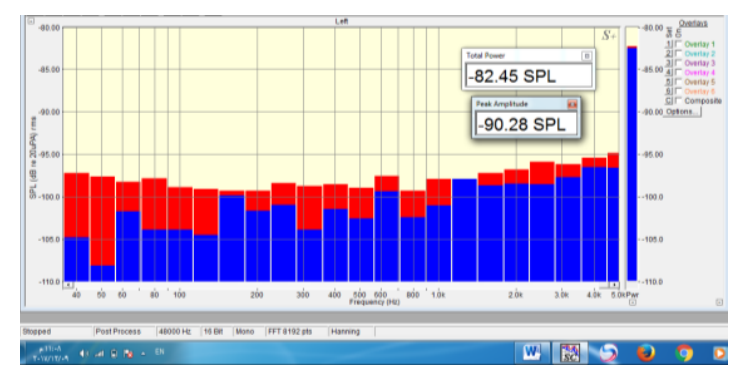

(a)

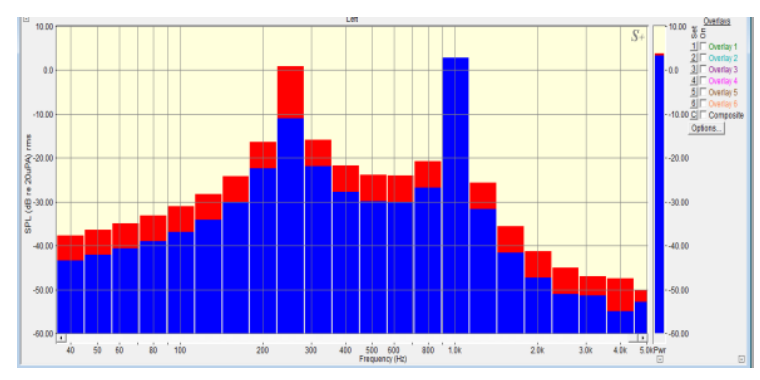

(b)

Figure (19):Experimental (SPL) for Two Rooms When close the Partition Between Rooms by One Sandwich Panel 100mm Thickness for Core,(a) Resaved Room.(b) Sources Room.

Table (4) provides the comparison results between theoretical and experimental and error percentage.

Table (4): Comparison (STL) Results Between Theoretical and Experimental and Error Percentage.

\begin{tabular}{|c|c|c|c|c|c|c|c|}
\hline $\begin{array}{c}\text { One Third } \\
\text { Octave Band } \\
\text { Frequency }(\mathrm{Hz})\end{array}$ & $\begin{array}{l}\text { Experimenta } \\
\text { I STL dB }\end{array}$ & $\begin{array}{l}\text { Theor } \\
\text { etical } \\
\text { STL } \\
d B\end{array}$ & $\begin{array}{c}\text { Error } \\
\%\end{array}$ & $\begin{array}{c}\text { One Third } \\
\text { Octave } \\
\text { Band } \\
\text { Frequency }(\mathrm{Hz})\end{array}$ & $\begin{array}{c}\text { Experim } \\
\text { ental STL } \\
d B\end{array}$ & $\begin{array}{l}\text { Theoretic } \\
\text { al STL dB }\end{array}$ & Error\% \\
\hline 100 & 5 & 4.4 & 12 & 1600 & 22 & 20.2 & 8.18 \\
\hline 200 & 10 & 8.56 & 1.44 & 2000 & 35 & 33 & 5.71 \\
\hline 250 & 13 & 12.1 & 6.92 & 2500 & 41 & 38 & 7.32 \\
\hline 500 & 20 & 18.4 & 8 & 3150 & 42 & 46.3 & 10.23 \\
\hline 800 & 37 & 35.7 & 3.714 & 4000 & 44.6 & 47.12 & 5.65 \\
\hline 1000 & 42 & 39.4 & 6.2 & 5000 & 48.1 & 44.8 & 6.86 \\
\hline
\end{tabular}

Figure (20) shows the comparison STL result among the experimental and theoretical. The STL curve was appeared that the mass law region was increased by rate $6 \mathrm{~dB}$ for each frequency band. The coincidence region is shown at frequency $1600 \mathrm{~Hz}$, where a dip in value STL values.

Figure (5.48) shows the critical frequency value was became in down the frequency band, that due to the effect of using the sandwich panel $50 \%$ thickness higher than from using one sandwich panel have $50 \mathrm{~mm}$ thickness for core, this is consistent with the literature of Nielsen[15].The value of STL are obtained in this case was higher by $10 \mathrm{~dB}$ than the values are obtained when is used one sandwich panel have $50 \mathrm{~mm}$ thickness core. 
Journal of University of Babylon for Engineering Sciences, Vol. (26), No. (6): 2018.

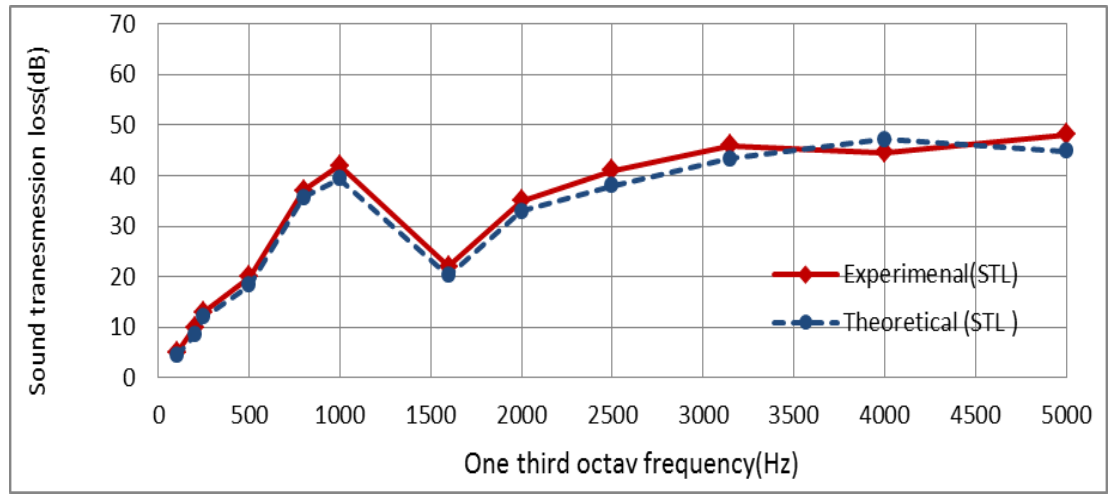

Figure (20): Comparison Theoretical and Experimental, STL Closed the Partition by One Sandwich Panel.

Figure (21) appears the FEM models sound pressure inside the rooms.

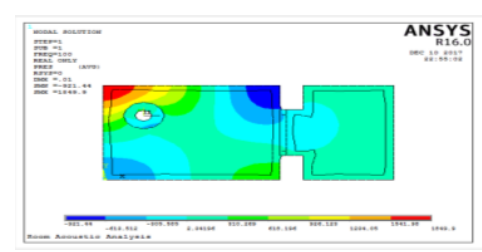

$\mathrm{Fn}=100$

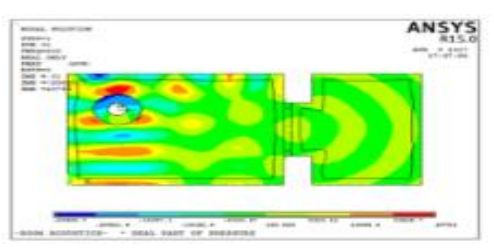

$\mathrm{Fn}=500$

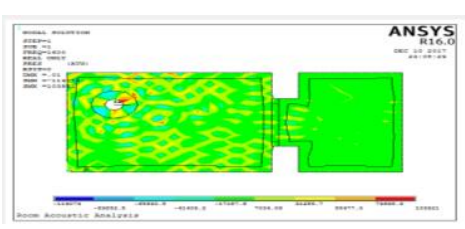

$\mathrm{Fn}=1600$

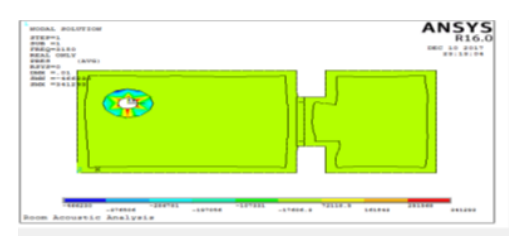

$F n=3150$

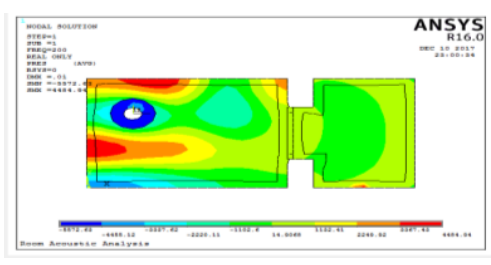

$F n=200$

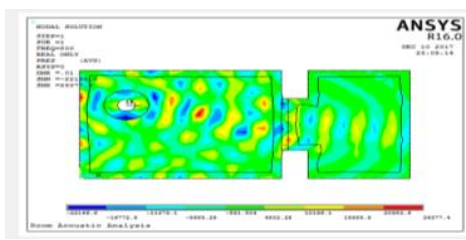

$\mathrm{Fn}=800$

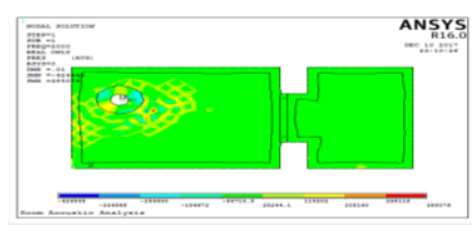

$\mathrm{Fn}=2000$

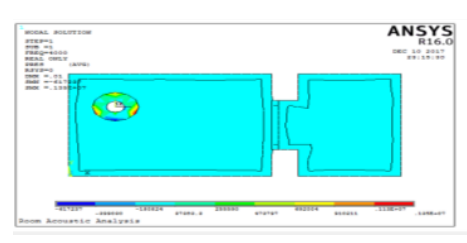

$\mathrm{Fn}=4000$

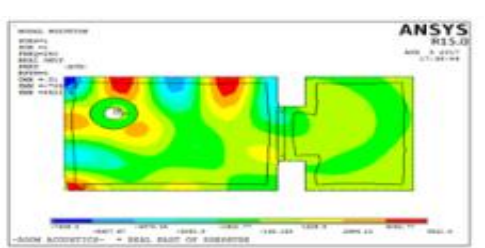

$F n=250$

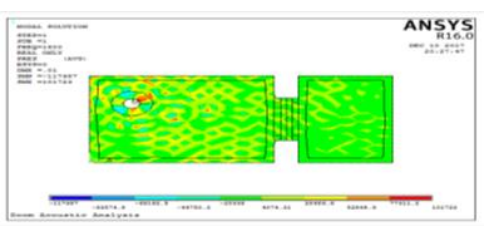

$\mathrm{Fn}=1000$

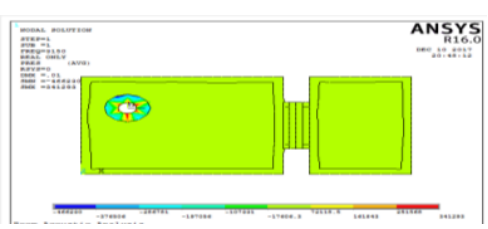

$\mathrm{Fn}=2500$

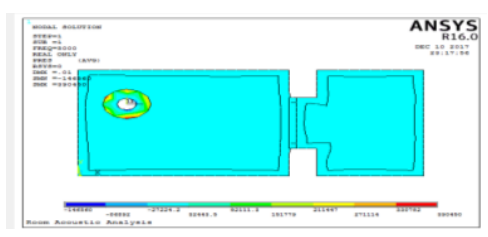

$\mathrm{Fn}=5000$

Figure (21):FEM Models Sound Pressure for Case Study Closed the Partition Between Two Rooms by Using One Sandwich Panel (100) mm Thickness Core. 


\section{Conclusions}

Four cases studies to calculate the sound transmission loss between two rooms are applied, the conclusions for this case as flowing:

1 - In open the partial between the two rooms the STL values are stable and low, because most the sound energy transmission from the source to receive room.

2- When closing the parietal by one sandwich panel 50mm thickness core the higher value $39 \mathrm{~dB}$ was appeared in mass law region, and the stiffness region appeared in very low frequencies, resonance panel region appears from (200 and 500) Hz.

3- The highest values of STL when using two-sandwich panel. This indicates an increase in the improvement of sound loss. And higher value (STL) was $48 \mathrm{~dB}$ in damping region.

4 - When using one sandwich panel with $100 \mathrm{~mm}$ core thickness. It shows come down in the critical frequency value in the frequency band due.

\section{References}

[1] "Multi-part Document BS EN ISO 140 - Acoustics. Measurement of sound insulation in buildings and of building elements", https://doi.org/10.3403/BSENISO140

[2] Kwanju Kim, Junheon Lee and Daeyong Kim, 2012. "A Study on the Vibroacoustic Analysis of Aluminum Extrusion Structures", Computer-Aided Design \& Applications, PACE (2).

[3] Edwin Reynders, Robin S. Langley b, Arne Dijckmans a and Gerri Vermeir, 2014, "A hybrid finite element - statistical energy analysis approach to robust sound transmission modeling", Journal of Sound and Vibration, 333 Vol. (682), Pg. (4621-4636).

[4] Raef Cherifa and Noureddine Atalla, March 2015, "Experimental investigation of the accuracy of a vibroacoustic model for sandwich-composite panels", Acoustical Society of America., Vol. (137), No. (3), Pg. (1541-1550).

[5] MP Arunkumar, Jeyaraj Pitchaimani1, KV Gangadharan1 and MC Lenin Babu, 2016, "Sound transmission loss characteristics of sandwich aircraft panels: Influence of nature of core", Journal of Sandwich Structures and Materials.

[6] Phillips, 2012, "sound transmission loss characteristics of plywood based sandwich panels", A thesis for Degree of Master of Engineering in the Department of Mechanical Engineering University of Canterbury.

[7] Cowan, 2013,"Sound Transmission Loss of Composite Sandwich Panels" Thesis for the Degree of Master of Engineering, University of Canterbury, Department of Mechanical Engineering Christchurch, New Zealand, and pg. (116).

[8] Quirt and Nightingale, 2008, “Airborne Sound Insulation in Multi-Family Buildings Archived Content", construction Technology Update March, No. (66).

[9] Fahy, 2012, "Sound and Structural Vibration: Radiation, Transmission and Response 7.2, Numerical Analysis of Sound Fields", Technology \& Engineering, Pg. (273-274).

[10] Ever J. Barbero, 2007, “Finite Element Analysis of Composite Materials", CRC Press.

[11] Coupled Field, Acoustics (UP19980818). www.ansys.stuba.sk/html/guide 55/gcou/GCOU4.htm.

[12] Muaid Adnan Abid Shhatha Al Zahid, 2016, "Impact Resistance of Cambered Reactive Powder Concrete Slabs With Steel Stiffeners", DP Thesis; Babylon University, College of Engineering Civil Engineering Department. 
Journal of University of Babylon for Engineering Sciences, Vol. (26), No. (6): 2018.

[13] Simona Moschini, 2014, "Vibroacoustic modeling of sandwich foam core panels", Doctoral Program in Mechanical Engineering, Politecnico Di Molano, Italy, pg. (194).

[14] Moore and Lyon, 1990, "Sound Transmission Loss Characteristics of Sandwich Panel Constructions" Journal of the Acoustical Society of America,Vol. (89), Pg. (777-791).

[15] Nilsson, 1990, "Wave propagation in and sound transmission through sandwich plates", Journal of Sound and Vibration, Vol. (138), No (1), pg. (73-94). 
Journal of University of Babylon for Engineering Sciences, Vol. (26), No. (6): 2018.

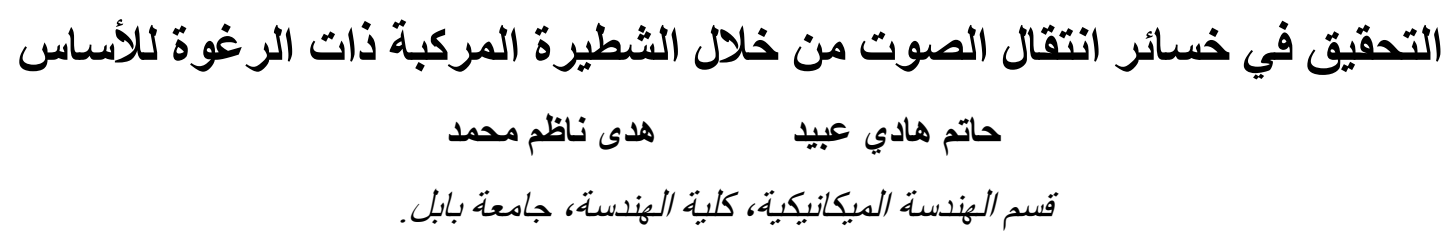

drhatemhadi@yahoo.com

huda.saadi.abd@gmail.com

الخلاصة

في السنوات الماضية، تم زيادة طلب العملاء و المستهكين للحصول على الاداء الصوتي. حيث اصبحت خصائص الاهنزاز و الضوضاء من معايير التصميم المهمة. يتم اعتبار السلوك الاهنزاز - الصوتي ولي ولئي

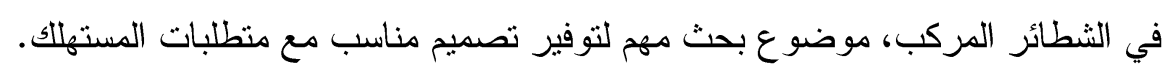

يستخدم طريقة شدة الصوت على نطاق واسع لقياس خسارة انتقال الصوت بين غرفتين. وتستخدم هذه الطريقة مع المو اد المركبة التي تتكون من طبقتين من الصلب بينهما طبقة واحدة للأساس. يتم في هذا

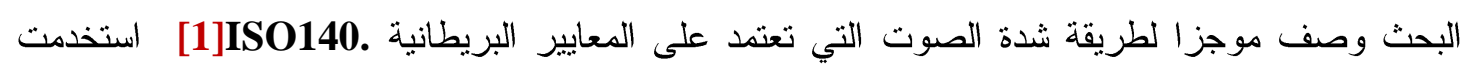

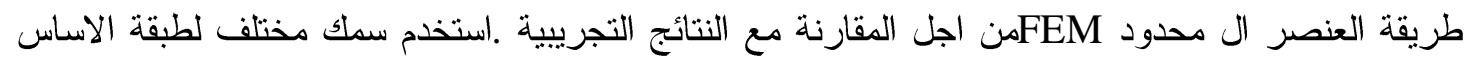
لار اسة تأثير ذلك على مقدار خسائر الانتقال الصوتي. وتظهر النتائج التجرييية والنظرية، أن قيمة خسارة الانتقال الصوتي تزداد بمعدلات (6 ديسييل)، عندما بتضاعف سمك الاساس.

الكلمات المفتاحية: - طريقة شدة الصوت، خسائر الارسال الصوتي، الثطبرة المركبة، تحليل الاهتزاز الصوتي. 